\title{
A interdisciplinaridade entre design gráfico e comunicação
}

Interdisciplinarity between graphic design and communication

SAGIN, Lis Antunes; Faculdade Pitágoras

lissagin@gmail.com

\author{
GOMES, Rogério Zanetti; Mestre; Faculdade Pitágoras \\ rogerioghomes@gmail.com
}

\begin{abstract}
Resumo
Neste trabalho explora-se a interdisciplinaridade como um instrumento de união entre duas disciplinas de comunicação, o design gráfico e a comunicação, na prática da profissão. A pesquisa foi desenvolvida por meio de revisão bibliográfica; Concluiu-se, com base em um case relacionado à revista "CLAUDIA", que a unificação entre essas duas áreas trouxe complexidade e sucesso ao projeto da mesma, de forma sutil e completa.
\end{abstract}

Palavras Chave: Design gráfico. Comunicação. Interdisciplinaridade. Aplicação prática.

\begin{abstract}
In this paper we explore interdisciplinarity as an instrument of union, between the two disciplines of communication, graphic design and communication, practice of the profession. The research was conducted by reviewing literature; It is exposing a case related to magazine "CLAUDIA" pointing out how this unification has brought success to the complexity and design in a subtle and complete.
\end{abstract}

Keywords: Design graphic. Communication. Interdisciplinary. Practical application

\section{Introdução}

Neste artigo, busca-se explorar a interdisciplinaridade entre Design Gráfico e comunicação com base em especialistas e profissionais da área que já discutiram o tema. Assim, por meio de uma revisão bibliográfica, espera-se encontrar respostas e justificativas para a interação, na prática, dessas duas áreas distintas.

Segundo Villas-Boas (2007, p. 49), "a interface entre design e comunicação é direta, ainda que cada uma dê pesos diferenciados a alguns aspectos - o que, em última análise, distingue uma da outra." Objetiva-se, desse modo, compreender, de forma mais ampla, ambos os campos de atuação, para que se possa esclarecer o modus operandi de cada uma dessas vertentes e quando a união entre as mesmas ocorre.

A interdisciplinaridade é um tema atual e ocorre, com frequência, na prática da profissão, a pesquisa fundamenta-se em um estudo histórico que busca compreender como o design e a comunicação foram inseridos no cotidiano da população em geral e tornaram-se conhecidos e de utilidade pública, assim como, pretende esclarecer e compreender a união de

Projética Revista Científica de Design I Universidade Estadual de Londrina I V.2 I N.1 I Junho 2011 
Lis Antunes Sagin; Rogério Zanetti Gomes

ambas as áreas e entender como se dá a interdisciplinaridade.

\section{Interdisciplinaridade}

Segundo Fazenda (2003), a interdisciplinaridade surgiu na década de 1960, como resposta a necessidades da época. Com o objetivo de solucionar questões sociais emergentes, várias áreas do saber se uniram para encontrar respostas para problemas sociais, econômicos e políticos.

No Brasil, a repercussão desses estudos interdisciplinares começou no fim da década de 1960, porém, por falta de conhecimento sobre o assunto, este era um campo de estudo sem muitos esclarecimentos. Este fato ocorria pela ausência de pesquisadores que conheciam o seu verdadeiro significado, o que gerou distorções.

A interdisciplinaridade, no Brasil, foi discutida como um modismo e acabou sendo utilizada, demasiadamente, como um conceito a ser estudado e aplicado, mesmo sem o devido conhecimento sobre o assunto. Este primeiro impacto que este estudo teve na sociedade educacional foi de euforia, pois não se atentou que a sua execução era de difícil realização, na época, devido aos estudos escassos.

Já no fim da década de 1970, surgiu a primeira produção significativa sobre o tema, escrita por Hilton Japiassú, momento em que se iniciou um verdadeiro avanço nos estudos nesta área. As especulações feitas por Japiassú e por inúmeros estudiosos, como Gusdorf, Smirnov, Apostel e Mircea Aliade, ajudaram a compreender os motivos e as finalidades da existência dos projetos interdisciplinares. Para Fazenda (2003, p. 28):

\footnotetext{
Osavançosmaissignificativos dessegrupo em relaçãoà interdisciplinaridade poderiam ser assim sintetizados: - a atitude interdisciplinar não seria apenas resultado de uma simples síntese, mas de sínteses imaginativas e audazes. - interdisciplinaridade não é categoria de conhecimento, mas de ação. - a interdisciplinaridade nos conduz a um exercício de conhecimento: o perguntar e o duvidar. - entre as disciplinas e a interdisciplinaridade existe uma diferença de categoria. - Interdisciplinaridade é a arte do tecido que nunca deixa ocorrer o divórcio entre seus elementos, entretanto, de um tecido bem trançado e flexível. - a interdisciplinaridade se desenvolve a partir do desenvolvimento das próprias disciplinas.
}

Com o amadurecimento e o desenvolvimento conceitual sobre o tema, a interdisciplinaridade passou a ser mais conhecida e aplicada no sistema educacional, porém seu conceito ainda era pouco conhecido.

De acordo com Carlos (2009), existem inúmeras interações disciplinares e uma delas é a interdisciplinaridade, que possui cinco níveis, sendo eles: Interdisciplinaridade Heterogênea, Pseudo-Interdisciplinaridade, Interdisciplinaridade Auxiliar, Interdisciplinaridade Compósita e Interdisciplinaridade Unificadora.

\section{Interdisciplinaridade heterogênea}

Conhecida também como "enciclopedismo", auxilia um profissional a utilizar aspectos de outras áreas e concluir projetos através das mesmas. 
Pseudo-interdisciplinaridade

Neste caso, uma área utiliza-se de uma disciplina ou de seus conceitos teóricos; a associação destas duas áreas é feita por meio de conceitos considerados "neutros", portanto, não há, exatamente, uma integração, o que faz desta uma falsa interdisciplinaridade.

\section{Interdisciplinaridade auxiliar}

Ocorre quando um campo disciplinar pega emprestado conceitos de outra área, apenas ocasionalmente, ou até mesmo de forma mais duradoura, porém, isso acontece somente quando uma se vê obrigada a utilizar os métodos da outra.

\section{Interdisciplinaridade compósita}

Esta é solicitada quando há grandes problemáticas sociais a serem resolvidos, como: guerra, fome, violência, poluição entre outros. Esses campos se aglomeram e buscam soluções técnicas para os problemas, porém não há uma integração real entre eles, assim como, nenhuma variante ou mudança em seus métodos.

\section{Interdisciplinaridade unificadora}

Neste caso, há uma integração entre os domínios e os métodos das disciplinas envolvidas; este nível de integração só poderá ocorrer com uma detalhada pesquisa científica. Pode ocorrer, neste caso, até mesmo uma unificação entre as disciplinas, o que pode gerar a formação de outra, com aspectos de ambas.

A vertente interdisciplinar que mais se enquadra na unificação entre design e comunicação social é a interdisciplinaridade auxiliar, que ocorre quando uma disciplina se vê buscando os conceitos de outra, ocasionalmente ou com frequência, a fim de concretizar tarefas. A interdisciplinaridade não consiste no abandono dos significados e dos conteúdos das disciplinas ou áreas envolvidas, mas na utilização dos conceitos de dois ou mais campos para o desenvolvimento ou para a concretização de um projeto.

\section{Design gráfico}

Neste estudo, não se pode fugir da discussão maçante que diz respeito à confusão etimológica e ao uso correto da palavra design, especificamente, no Brasil, já que o termo foi importado da língua inglesa.

De acordo com Cardoso (2004), na cultura inglesa, a definição da palavra design se deu pela referência à ideia de plano, arranjo ou estrutura, porém o vocábulo vem do latim "designare", um verbo que pode ter dois sentidos: designar e desenhar. O autor lembra, ainda, que:

Projética Revista Científica de Design I Universidade Estadual de Londrina I V.2 I N.1 I Junho 2011 
A origem mais remota da palavra está no latim designare, verbo que abrange ambos os sentidos, o de designar e o de desenhar. Percebe-se que, do ponto de vista etimológico, o termo já contém nas suas origens uma ambigüidade, uma tensão dinâmica, entre o aspecto abstrato de conceber/projetar/atribuir e outro concreto de registrar/configurar/formar. (CARDOSO, 2004, p. 4).

O design diz respeito ao desenvolvimento de projetos que envolvem planos, esboços ou modelos, ou seja, de forma diferente da arquitetura ou da engenharia, que desenvolve projetos tridimensionais, porém, como o design tem o costume de desenvolver móveis, as três atividades tendem a se relacionar na prática.

O processo de industrialização desencadeou inúmeras mudanças no perímetro urbano e transformações nas formas de relacionamento entre as pessoas, o que causou o desenvolvimento da comunicação social. No Brasil, as mudanças comportamentais, que vinham ocorrendo desde o século XIX, devido ao aumento populacional e à busca por lazer nos momentos de folga, acabaram por desencadear a necessidade de uma melhor sinalização para os passatempos populares. O público assalariado e letrado cresceu, significativamente, o que gerou um maior investimento no setor e o desenvolvimento de novos materiais impressos e de máquinas para os produzirem. Isto possibilitou a popularização dos meios de comunicação já usados, como o jornal e os livros, mas também de outros, mais recentes, como o cartaz, o catálogo, a embalagem e a revista ilustrada. Nesse sentido, Cardoso (2004, p. 38).assinala que:

Esse aumento da quantidade de indivíduos vivendo em um pequeno espaço ocasionou transformações profundas na natureza das relações entre eles. As pessoas começavam a se deslocar de casa para o trabalho, viajando na companhia de estranhos em transportes como ônibus e o bonde, característicos da nova experiência urbana. [...] Entre as mercadorias cujo consumo mais se expandiu no século 19 estão os impressos de todas as espécies, pois a difusão da alfabetização nos centros urbanos propiciou um verdadeiro boom do público leitor.

Na segunda metade do século XIX, os métodos de divulgação já eram mais abundantes e acessíveis financeiramente, o que propiciou a modernização do processo de fabricação destes materiais. Com toda esta nova demanda, passou-se a exigir muita criatividade dos tipógrafos, compositores, desenhistas e gravadores, pois estes deveriam criar uma linguagem visual simples e compreensível, adequada ao público da época e às novidades das possibilidades de produção.

Nessa época, o mercado editorial começou a se desenvolver graças à união entre a necessidade de conhecimento, a facilidade de produção e o inesperado aumento de interesse do público consumidor. Esses fatores tornaram mais acessíveis os cursos de produção de livros, revistas, jornais, gravuras e fotografias. Impressos, como revistas femininas, por exemplo, eram impensáveis na década de 1950, mas devido à euforia de acontecimentos, algumas décadas depois, já eram populares.

Nesta mesma época, começou a ascensão da classe média na Europa, nos Estados Unidos (EUA) e da elite brasileira. Desse modo, houve uma nova definição de opiniões de consumo, em vários setores, como o do vestuário, de objetos decorativos, entre outros. Para estas classes, as diferentes opiniões em relação ao consumo eram vistas como a identidade desse grupo, pois definiam a personalidade dos indivíduos que pertenciam a ele. Conforme Cardoso (2004, p. 54):

Egresso do seu anonimato na fábrica ou na oficina, surge nessa época uma nova figura do designer como profissional liberal: um homem (quase sempre) que 
A interdisciplinaridade entre design gráfico e comunicação compartilhava das mesmas origens e dos mesmos gostos de consumidores que buscavam nessas produções, mais do que uma simples qualidade construtiva, uma afirmação da sua identidade social.

Para o gerenciamento desse novo padrão de vida tornou-se necessária a formação de um profissional voltado para este tipo de projeto. Foi nesse momento que os designers começaram a se unir e, como, nessa época, eles trabalhavam nas fábricas e pertenciam à mesma classe social dos consumidores dos seus produtos, tinham um conhecimento maior dos seus costumes e das suas vontades, o que possibilitou o desenvolvimento de projetos bastante focados e completos.

Essa preocupação geral de ser olhado como único pelos outros surgiu no século XIX, pois, antes dessa época, esta era uma realidade apenas para os reis e a nobreza, que eram os únicos que possuíam poder aquisitivo para o consumo.

Esta notável mutação das classes sociais gerou dificuldade na hora de se definir as tendências, de modo especial, nas áreas urbanas, contexto em que se utilizava as habilidades do designer. Nesse sentido, as moradias, as vestimentas e as possibilidades de consumo por toda a população, devido à acessibilidade do preço e a necessidade de se caracterizar por meio de bens, resultaram em uma vulgarização do luxo nunca antes vista.

Nessa época, podia-se escolher o que se queria mostrar ou ocultar em relação à própria personalidade ou à moradia, por meio das fachadas, dos móveis e ornamentos. O interior das casas funcionava como um refúgio, principalmente para as mulheres, que encontravam, ali, uma forma de expressarem a sua criatividade, mesmo com objetos desnecessários e supérfluos. A partir deste momento, o designer se transformou em um profissional necessário e em evidência.

\section{Teoria da comunicação}

A comunicação humana é formada por símbolos e pode ser analisada de forma semântica ou sintática. Esta comunicação é utilizada em um processo artificial "influenciada pela cultura", diferentemente de uma comunicação instintiva, como o ato de amamentar, onde a comunicação entre mãe e filho é natural. Conforme Flusser (2007, p. 90):

O objetivo da comunicação humana é nos fazer esquecer desse contexto insignificante em que nos encontramos - completamente sozinhos e "incomunicáveis", ou seja, é nos fazer esquecer desse mundo em que ocupamos uma cela solitária e em que somos condenados à morte - o mundo da "natureza".

O homem busca, na comunicação, uma forma de ludibriar-se e esquecer a ausência de sentido da vida solitária que está fadada a morte. Segundo Flusser (2007, p. 91), "o homem comunica-se com os outros; é um "animal político", não pelo fato de ser um animal social, mas sim por que é um animal solitário, incapaz de viver na solidão." A comunicação humana é desenvolvida com o propósito de armazenar informações, por meio de códigos e símbolos criados pelo homem, para que os acontecimentos não sejam esquecidos e a vida seja vivida. $A$ comunicação humana foi o recurso que o homem encontrou para o exercício dessas funções.

A diferença entre o diálogo e o discurso fica clara quando se observa o receptor da mensagem. Quando o indivíduo assiste à televisão, ele obtém inúmeras informações, tanto quanto em um diálogo, porém, independente do tipo de informação, em um diálogo, o indivíduo tem a oportunidade de ter voz ativa, argumentar e desenvolver uma reflexão sobre o tema, ou 
seja, há uma interação com o outro, o que não ocorre no discurso.

Pode-se observar que ambas que as formas de comunicação são dependentes uma da outra, porém, o que as diferencia é a distância exigida por cada uma. Para se estabelecer um diálogo, deve-se estar próximo e/ou introduzido no mesmo, porém, para se analisar um texto, não é necessária nenhuma interação ou vinculo com quem o produziu.

Independente da facilidade de comunicação, observa-se que o propósito dos discursos de afastar o homem da solidão está cada vez mais corrompido, pois a ausência de diálogos produtivos e o aumento da comunicação por discurso fazem com que o homem se sinta deslocado da produção dessa comunicação e, portanto, da história.

De acordo com Flusser (2007, p. 99), é possível classificar a estrutura da comunicação entre "semanticamente" ou "sintaticamente".

Se adotarmos o critério "semântico" os gêneros de comunicação serão catalogados conforme a informação transmitida, por exemplo, nas classes principais: informação "fática" (indicativo), informação "normativa" (imperativo), informação "estética" (condicional). Mas pode ser mostrada que os critérios "sintáticos" que ordenam os gêneros de comunicação conforme sua estrutura são adequados para preparar o campo para futuras análises "semânticas".

Os símbolos são representados por meio de traços, imagens, mas, principalmente, das cores. Cada cor possui um significado e elas transpassam as mensagens através das superfícies. Anteriormente ao período contemporâneo, quando o mundo vivia a Segunda Guerra Mundial, podia-se observar que as cores não eram muito exploradas e a superfície era mais cinzenta; outra percepção é que para a comunicação estas superfícies e cores não eram utilizadas com o intuito de comunicar.

A comunicação era predominantemente linear, mas, com a introdução das cores, observa-se a necessidade desta se tornar bidimensional. Essa forma de comunicação não é necessariamente nova, pois, desde os primórdios da humanidade, antes mesmo da palavra escrita ser desenvolvida, o ser humano se comunicava por imagens, através de superfícies. Mesmo depois da palavra escrita, as imagens permaneceram importantes, como observa Flusser (2007), pois o alfabeto só começou a se impor depois da invenção da imprensa, portanto, a contemporaneidade é um retorno à idade média, quando as imagens eram mais importantes do que as palavras.

Quando um indivíduo assiste a um programa de televisão ou a um filme, as informações que recebe através das imagens são relativamente codificadas para o mesmo, para que ele entenda exatamente o que deve entender e não desenvolva um pensamento complexo sobre o tema. Isto torna o receptor leigo, pois ele é apenas o que contempla. Para Flusser (2007, p. 130):

Os homens têm de se entender mutuamente por meio dos códigos, pois perderam o contato direto com o significado dos símbolos. O homem é um animal "alienado" (verfremdet) e vê-se obrigado a criar símbolos e a ordená-los em códigos, caso queira transpor o abismo que há entre ele e o "mundo". Ele precisa "mediar" (vermitteln), precisa dar um sentido ao "mundo".

Para que haja uma interação do cidadão com a imagem, é necessário que o mesmo se desloque de sua casa e se insira na sociedade, que vá a um mercado, por exemplo. É preciso que este faça uma análise das imagens que são produzidas por outros e expostas socialmente, pois as críticas e as observações do espectador serão a base para a classificação do valor de determinada imagem perante a sociedade. Quando uma imagem é complexa, ela se torna mais

Projética Revista Científica de Design I Universidade Estadual de Londrina I V.2 I N.1 I Junho 2011 
A interdisciplinaridade entre design gráfico e comunicação

interessante e completa de significados, porém, quando uma imagem é mais simples, ela é facilmente incorporada pela mente das pessoas e se torna mais familiar e confortável para as mesmas.

O homem contemporâneo permitiu que as imagens produzidas por televisores se tornassem um passatempo e um entretenimento maior do que qualquer outro. Estas imagens são codificadas por emissores de maneira que são facilmente aceitas por seus receptores. Os receptores destas imagens são programados para não desenvolver um pensamento diferente do que é proposto, tornando-se facilmente controláveis e alienados. Segundo Flusser (2007, p. 156), esse "objetivo é alcançado por meio de diversos métodos, como, por exemplo, a inflação de imagens, que impossibilita qualquer escolha, ou então a aceleração da sequência de imagens."

Os métodos de penetração destes códigos na mente dos receptores foram tão bem desenvolvidos, de modo que, se o indivíduo não quiser mais ser atingido por eles, não poderá apenas romper estes estímulos ou deixar de se expor, deverá se afastar definitivamente de todo tipo de comunicação social.

O transporte atual de imagens, por meio de televisores, filmes, impressos ou computadores, vem cumprindo o seu objetivo comportamental de transformar os receptores em objetos. Esses novos meios conectam os receptores entre si, possibilitando uma maior interação entre eles, o que abre uma nova vertente para a decodificação dos significados. No caso da internet, por exemplo, o emissor transmite uma mensagem através de uma imagem e ela é recebida pelo receptor, que a absorve e a transmite, novamente, para a rede, demonstrando para outros o que assimilou dela. "Dito de modo sucinto: os novos meios, da maneira como funcionam hoje, transformam as imagens em verdadeiros modelos de comportamento e fazem dos homens verdadeiros objetos." (FLUSSER, 2007, p. 159). A reestruturação destes novos meios poderá modificar a forma como o receptor se porta perante uma imagem/mensagem, ou seja, poderá tirá-lo da alienação de ser um objeto e torná-lo um portador dos significados. Para a produção destes códigos, é preciso conhecer e prever o comportamento da sociedade, de modo que as mensagens sejam elaboradas para cumprir a sua finalidade de influenciar os comportamentos. A observação da sociedade e do que é produzido por ela é uma das formas mais efetivas de compreendê-la. As empresas que buscam internalizar as suas mensagens na mente dos receptores se utilizam de especialistas que trabalham na codificação de imagens e mensagens. Os publicitários, por exemplo, objetivam conhecer seu público-alvo, seus desejos e necessidades, para que possam satisfazê-los de acordo com o que é disponibilizado. Essa compreensão social é necessária para que os profissionais da comunicação possam utilizar-se das reações e vivências da sociedade a fim de concluir sua função de entretenimento.

\section{Interdisciplinaridade entre design gráfico e comunicação}

Como observa Villas-Boas, o Design foi determinado como uma área de programação visual (ou comunicação), que pode variar também entre desenho industrial e projeto de produto, em um curso superior regulamentado pelo ministério da educação. A diferença entre o design gráfico e a publicidade ainda hoje é estudada e muito citada entre os teóricos da área. É irrefutável que as diferenças existem, tais como o fato do design gráfico ser bidimensional, aplicado por meio de impressos, e o projeto de produto ser tridimensional, utilizado na produção de objetos reais, porém, apenas esta distinção não aborda com profundidade o tema.

$\mathrm{O}$ design em si não deve ser considerado apenas como desenho quando pode ser 
aplicado a estruturas, objetos, estampas, e o projeto gráfico não pode funcionar sem a interferência do design em sua produção. O design é uma área de estudos concisa, mas não fechada, e, portanto, fundamentalmente interdisciplinar, pois sofre e causa interferências na área da comunicação social. Neste sentido, Villas-Boas $(2007$, p.48) ressalta que:

Embora pertença a uma área de conhecimento específica e em processo de autonomização enquanto campo intelectual, o design gráfico é essencialmente interdisciplinar, tendo estreita interface principalmente com a comunicação social, as artes plásticas e a arquitetura.

A relação entre as duas áreas, design gráfico e comunicação, é direta, mesmo que cada uma tenha peculiaridades que as distanciam e as tornam diferentes. Na área de comunicação visual, observa-se que a coerência visual de um impresso é extremamente necessária na hora de impressionar e comunicar, e é neste momento que o design se insere. Na comunicação social como no design vale ressaltar que a disposição de cada elemento ou a ausência deles é significativa para a comunicação e representa alguma junção num impresso.

A ausência de especificação do design gráfico ocorre não apenas no sentido teórico e educacional, mas também na inserção prática. $O$ design é regulamentado de acordo com o ministério da educação, porém o profissional não precisa, necessariamente, recorrer a esta formação para exercer tal atividade e, dessa mesma forma, ocorre com a publicidade.

O Brasil é um dos poucos países onde o design gráfico possui um espaço educacional firmado, entretanto, devido à pouca delimitação sobre as vertentes deste campo de atuação, a profissão pode ser desenvolvida por indivíduos de outras áreas, o que é facilmente aceito e até incentivado. Muitos diretores de arte de agências de comunicação são publicitários; designers trabalham com comunicação e jornalistas se tornam redatores publicitários. Para Lima (1994):

Quem determina o que vem a ser um designer é o grupo que a sociedade coloca neste papel. Que no caso do brasileiro, vem a ser a universidade e as associações profissionais, instituições que selecionam os críticos de valor, o campo de atuação, os limites éticos, conhecimento e atitudes, enfim todos os elementos separam o profissional dos não-profissionais (apud VILLAS-BOAS, 2007, p. 51).

Ocasionalmente, o resultado disso é que, independente da formação e da área atuação, o profissional utiliza o termo designer pare definir-se, desde que acredite ser cabível ao termo. Observa-se que esta liberdade de uso, ocasionada pela ausência de determinação, pode fazer com que o termo seja utilizado de forma leviana, ou seja, independente da extensão de conteúdo determinada para este campo de atuação.

\section{As várias faces de "Claudia"}

A revista CLAUDIA foi criada em 1961, com um formato revolucionário, inteiramente voltado ao universo feminino e, desse modo, foi pioneira nesse segmento editorial. A publicação tem, geralmente, 191 páginas e é, atualmente, a revista feminina de maior circulação da Editora Abril. Ela aborda questões como: família, carreira, sucesso, dinheiro, moda, beleza, bem-estar, amor, sexo, além de temas contemporâneos pertinentes aos interesses femininos. No mês de outubro de 2011, a revista completa 50 (cinquenta) anos de vinculação, com uma circulação de 431 mil exemplares. 
A interdisciplinaridade entre design gráfico e comunicação

Este estudo tem o objetivo de apreender, por meio de uma análise, as características de interdisciplinaridade, entre o design e a comunicação, apresentadas nas capas da revista em questão. Para maior compreensão e linearidade, foram selecionadas para a análise as capas do mesmo mês de outubro, mês do seu aniversário, durante uma década, ou seja, de 2001 a 2010. Segue abaixo por meio deste artigo a análise de algumas características, previamente selecionadas, como: cor, diagramação, fotografia, logo, slogan e tipografia, nas publicações da revista. Assim, buscou-se demonstrar, por meio de características que pertencem ao design e à comunicação, em termos de diagramação e compreensão do público-alvo, respectivamente, o que leva a revista a ser tão bem aceita junto à comunidade feminina, por tantos anos. Observou-se, desse modo, como ambos, o design e a comunicação, interferem nessa relação através do layout.

Em relação à diagramação da capa no ano de outubro de 2001 a fotografia está situada ao lado direito, a logo "CLÁUDIA", está no topo da diagramação. Os títulos, subtítulos e as descrições de conteúdo estão ao lado direito. Abaixo apenas as inscrições "Edição de aniversário". Na edição de 2002 ao centro da capa está a modelo, aos lados e abaixo estão as inscrições sobre o conteúdo da revista. O endereço do site está inserido na letra "I", e a frase "Edição de aniversário" esta dentro da letra "C". Em 2003 o título mantém-se acima na publicação, ao centro da capa a foto de uma atriz enfatizada, com a tipografia aos lados direito e esquerdo de seu rosto de forma disforme sem seguir nenhum padrão predeterminado, o logotipo da Editora Abril se encontra no topo ao lado direito, como nos anos de 2001 e 2002. Na publicação de 2004 o título se mantém no topo como nas outras edições e ao centro da publicação a modelo está evidenciada. O logotipo da Editora Abril abaixo no lado esquerdo e se mantém assim até 2010. Ao lado da fotografia as chamadas aparecem emoldurando seu semblante de modo que não seguem nenhuma estrutura ou padrão linear.

Especificamente no ano de 2005 foram produzidas três capas, o título "Cláudia" vem acima das três, como nas demais edições, com os outros elementos abaixo, aos lados e abaixo as chamadas com o conteúdo da revista. As mesmas não seguem linearidade. Ao centro a modelo ocupando todo o plano de fundo da publicação. Na capa de aniversário de 2006, a modelo aparece à esquerda, o título "CLAUDIA" acima, à direita um beija-flor e abaixo dele um espaço em branco. Abaixo da capa, os subtítulos e descrições. Na orelha, apenas uma fotografia da primeira revista, ao lado direito na parte superior, e á esquerda, até abaixo, subtítulos e chamadas sobre o conteúdo da revista. No canto esquerdo, há uma imagem de revista "Cláudia - Comida\&bebida". Em outubro de 2007, a modelo aparece ao centro. Como nas outras publicações, o título "CLAUDIA" está acima; aos lados da foto da modelo, as chamadas e os subtítulos aparecem de maneira disforme. Inserido no " $C$ " do título está o endereço do site e abaixo do mesmo estão as inscrições "Edição de aniversário. Edição verde".

Especificamente na capa de outubro de 2008, a modelo aparece do quadril para cima, em um plano médio encobrindo parte da logo "CLAUDIA", que fica acima, na diagramação; o endereço do site está na letra " $C$ ", como nas anteriores; e as descrições e os subtítulos aos lados do corpo da modelo. Abaixo do título, do lado direito, há a fotografia de um brigadeiro e, abaixo disso, a inscrição "Edição de aniversário". Na edição de 2009 acima na capa está o título "CLAUDIA" com os braços e cabeça da modelo encobrindo as letras "AU" e parte do " $D$ ". Inserido dentro da letra " $C$ ", está o endereço do site e dentro da letra " $A$ " e acima do braço da modelo, estão as inscrições "Edição de aniversário". Os subtítulos e as descrições se mantêm ao lado e abaixo como nas outras edições. Por fim na publicação de outubro de 2010 , a modelo está centralizada, com uma fotografia de corpo acima do joelho. A logo "CLAUDIA" está acima na diagramação e o endereço do site abaixo do segundo " $A$ ". Inseridas na letra " $C L$ " estão às inscrições "Edição de aniversário". As chamadas e os subtítulos estão ao lado da fotografia da

Projética Revista Científica de Design I Universidade Estadual de Londrina I V.2 I N.1 I Junho 2011 
Lis Antunes Sagin; Rogério Zanetti Gomes

modelo e abaixo.

A disposição do titulo "CLAUDIA", desde os primórdios da revista, vem no topo do layout da capa, com letras garrafais e com a fonte em maiúscula, de modo a destacar o nome, porém, por ser uma fonte fina, que permanece a mesma ao longo dos anos, e por apresentar apenas mudanças discretas na serifa, não tira a atenção da modelo que está na capa.

Observou-se que, até o ano de 2002, as modelos que posavam para a capa eram, em sua maioria, mulheres anônimas, e as fotografias, basicamente, um close dos rostos das modelos, as mesmas sempre sorridentes. Somente a partir de 2003, começaram a participar das capas mulheres famosas e reconhecidas, as celebridades. Depois do ano de 2008, a profundidade da fotografia passou a ser maior, do close para o plano médio, mostrando parte do corpo das modelos; foi quando as formas corporais começaram a ser valorizadas nas capas.

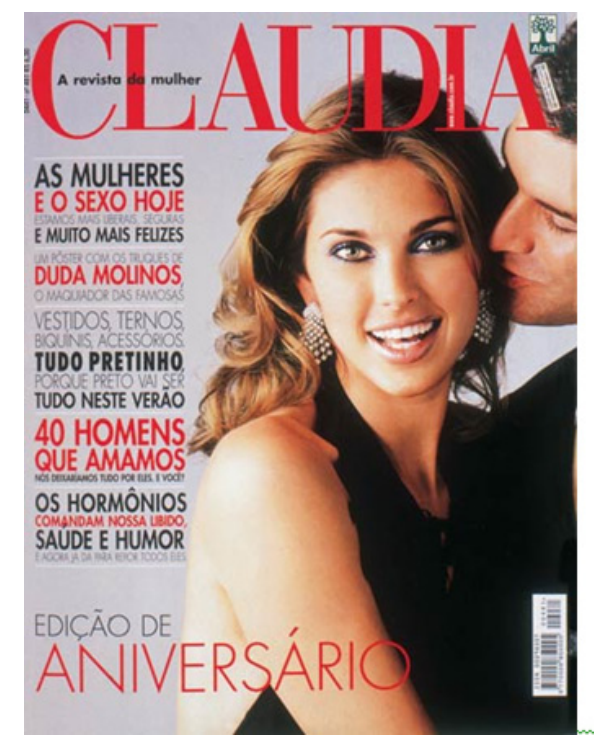

Figura 3 - Capa CLAUDIA

Fonte: Revista outubro 2001

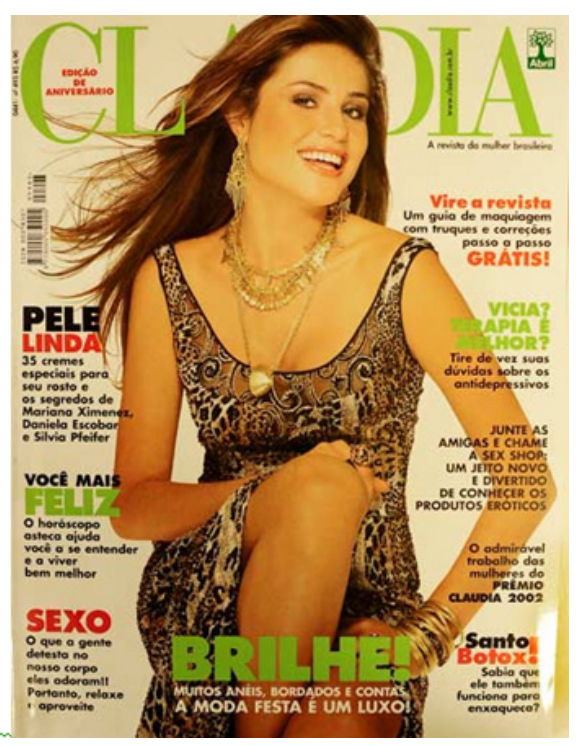

Figura 4 - Capa CLAUDIA

Fonte: Revista outubro 2002

A tipografia não obteve muitas variações ao longo dos anos, as fontes são longas, quadradas e legíveis nos anos de 2001, 2003 e 2006. Seu tamanho varia por entre as inscrições, entre maiúscula e minúscula. As edições de 2002, 2004, 2005, 2007, 2008, 2009 e 2010 seguiram um padrão de fontes, estas são arredondadas e legíveis, variando entre caixa alta e baixa nos subtítulos. As mesmas são expostas de maneira desorganizada e disforme, mas esta constância na desorganização demonstra de forma controversa a sua linearidade.

Em relação à década de 2000 , não há uma uniformidade nas cores que aparecem nas capas e nos títulos, pois estas variam entre: verde, vermelho, azul, branco, rosa, amarelo, laranja e até mesmo o dourado; quando uma cor está em evidência, ela pode variar em tons, entretanto, a única cor que prevalece na maioria delas - a partir de 2003 - é o branco, tanto no fundo, como no título, nas chamadas ou até mesmo nas linhas e no figurino das modelos. Nos anos de 2001 e 2002, o preto apresentou-se na tipografia e, algumas vezes, no figurino.

Ao lado da revista, na lombada do dorso, pode-se notar que, a partir dos anos 2000, especificamente em 2004, slogans foram incorporados; estes são variados e vêm com palavras em destaque, na mesma cor ressaltada na capa da edição, com o objetivo de incentivar a autoestima e a valorização da mulher, com palavras como: "sucesso", "você", "superbonita", "dinheiro", entre outras. Em 2004 o slogan era "Presentão: seu sonho de verão realizado". Entre os anos de 2005 e 2007, o slogan passou a ser fixo, desenvolvendo, assim, um foco, que

Projética Revista Científica de Design I Universidade Estadual de Londrina I V.2 I N.1 I Junho 2011 
A interdisciplinaridade entre design gráfico e comunicação demonstrava o interesse pelo desejo individual das leitoras, pois a inscrição era: "independente, sem deixar de ser mulher". Nos anos seguintes, entre 2008 e 2009, o slogan foi modificado para: "CLAUDIA mais que informa, transforma", e no ano de 2010 passou a ser: "CLAUDIA sempre você", seguindo o mesmo padrão anterior de cor e tipografia.

Quanto ao conteúdo abordado nas chamadas, observa-se que, nos anos de 2007, 2008 e 2009, havia muita ênfase na moda das décadas anteriores e na longevidade da revista. Observou-se, também, que, durante os seus 50 anos de sua existência, a publicação acompanhou as mudanças e os acontecimentos comportamentais e sociais que ocorreram ao longo do tempo, evidenciando-os nas capas das revistas, que refletem alguns desses eventos.

Nos anos 2000, o culto a celebridades passou a se destacar como interesse feminino, o público-alvo da revista, assim, modelos famosas passaram a ilustrar as capas da mesma a partir do ano de 2003 até hoje. Os efeitos visuais bidimensionais e a simplicidade das cores também são tendências evidentes na capa, como o gradiente, por exemplo.

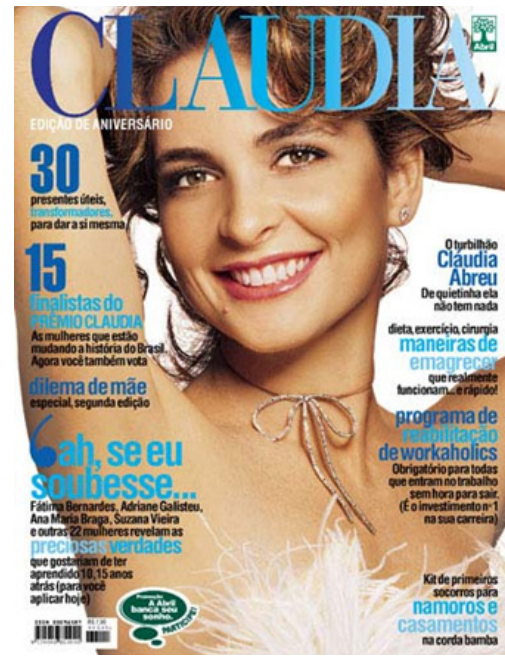

Figura 5 - Capa CLAUDIA Fonte: Revista outubro 2003

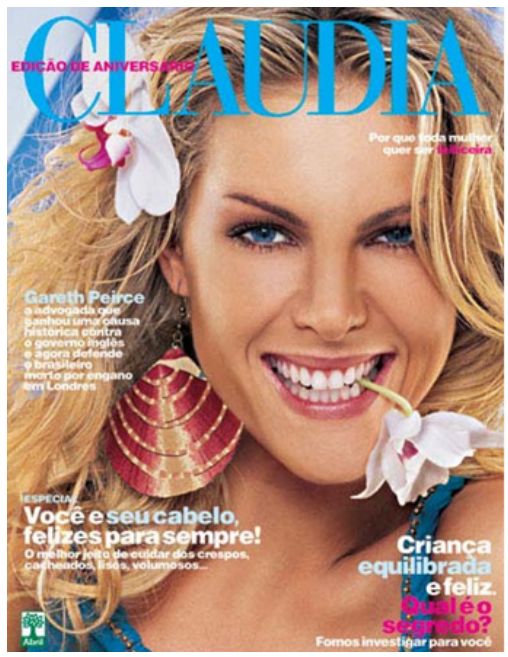

Figura 7 - Capa CLAUDIA Fonte: Revista outubro 2005

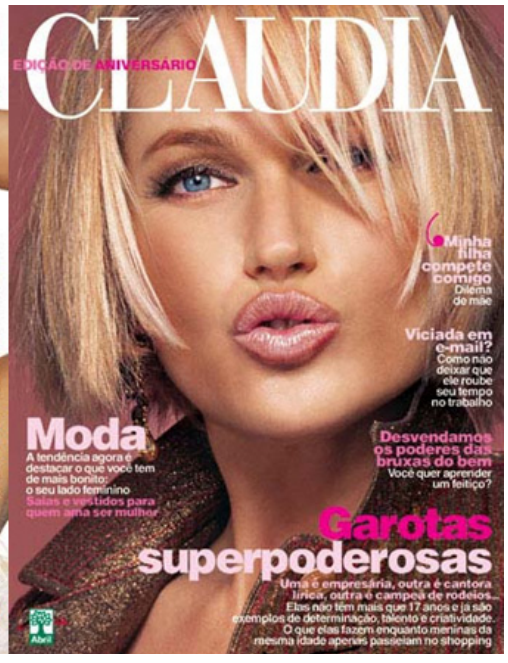

Figura 6- Capa CLAUDI

Fonte: Revista outubro 2004

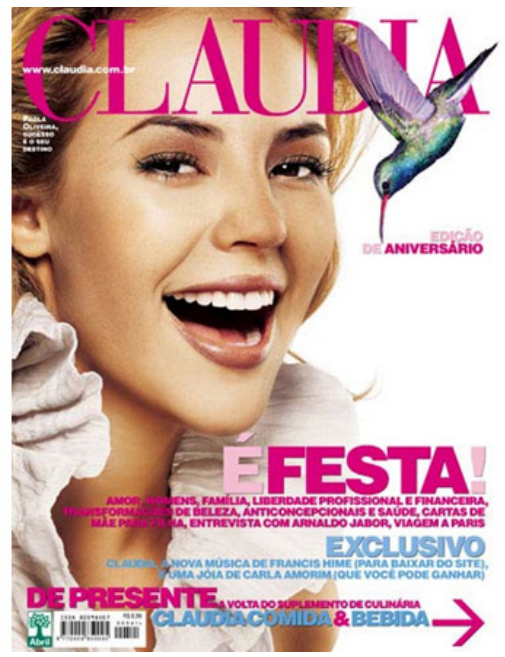

Figura 8 - Capa CLAUDIA

Fonte: Revista outubro 2006 


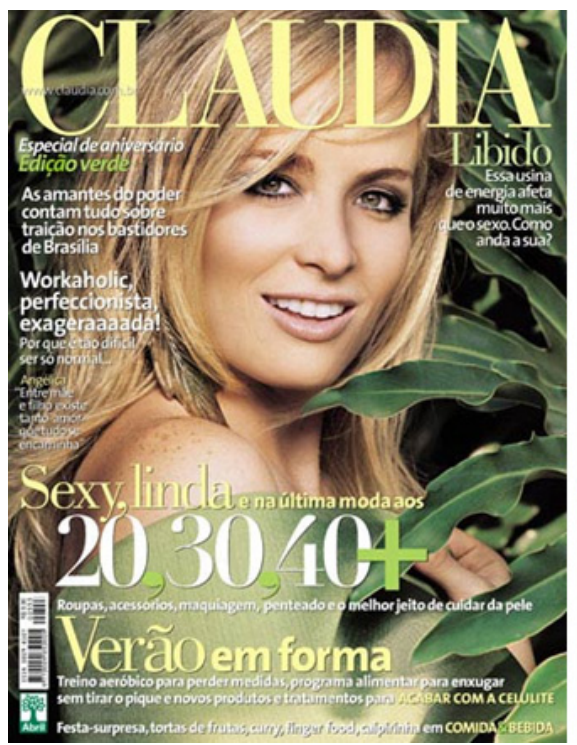

Figura 9 - Capa CLAUDIA Fonte: Revista outubro 2007

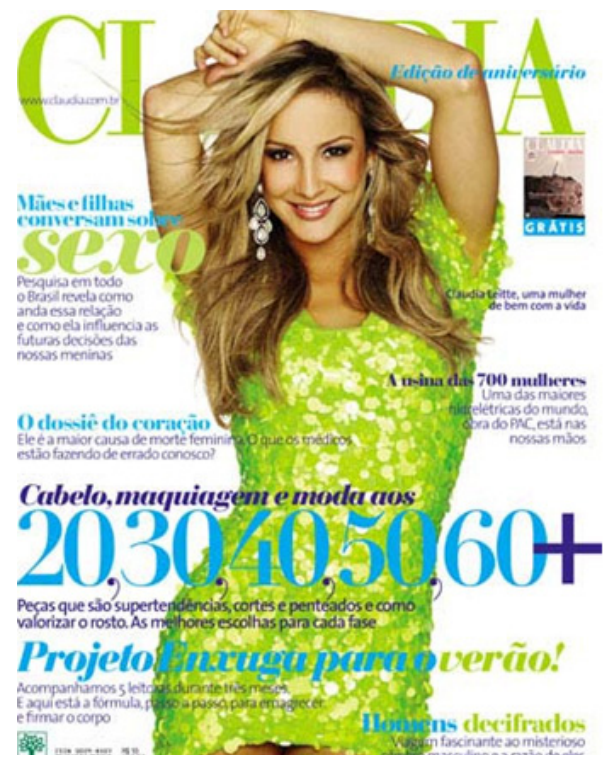

Figura 11 - Capa CLAUDIA

Fonte: Revista outubro 2009

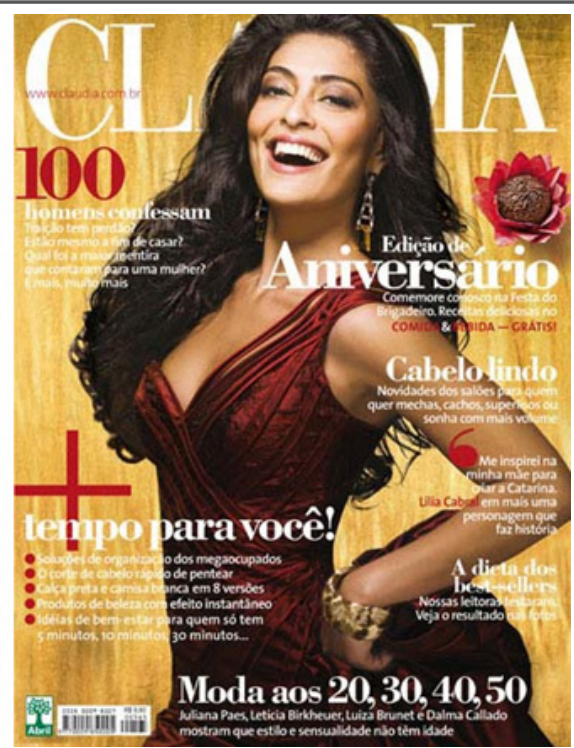

Figura 10 - Capa CLAUDIA

Fonte: Revista outubro 2008

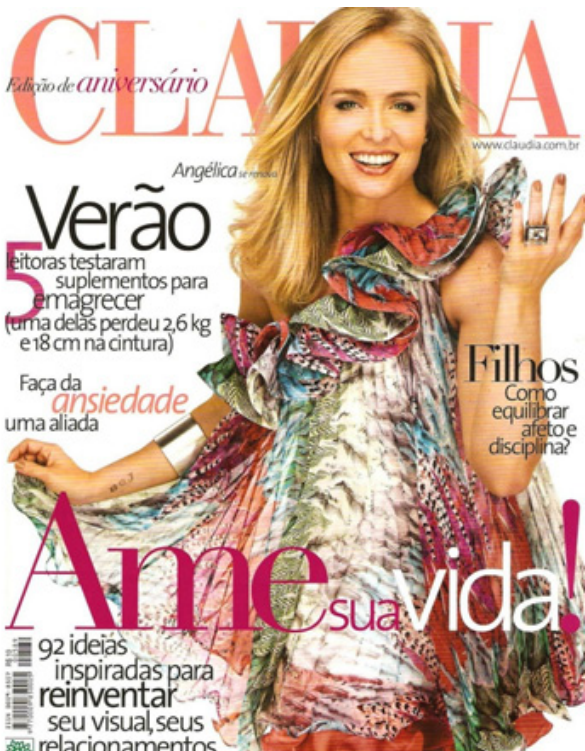

Figura 12 - Capa CLAUDIA

Fonte: Revista outubro 2010

As cores em destaque nas capas, muitas vezes, estão relacionadas às estações do ano e à moda vigente na época. No caso deste estudo, que o foco é outubro, é a primavera, porém as estações do ano não são, exatamente, demarcadas, no Brasil, o que faz com que este mês venha com uma ênfase maior no verão, com destaque para chamadas sobre a próxima estação. O colorido e as flores características da primavera aparecem em apenas algumas edições, como as de 2005, 2006 e 2010.

As inscrições do site da revista não aparecem de maneira linear, pois a cada ano são inseridas em um local diferente no layout, apesar de virem sempre próximas ao título, abaixo do mesmo, sobre o " $C$ " ou na letra " $L$ ". Observa-se que, em algumas edições - 2.003, 2004 e 2005 - elas sequer apareceram. A partir do ano de 2006, a inscrição passou a vir inserida no "C" de Cláudia, deixando esta posição apenas no ano de 2010, para dar lugar às inscrições relativas à edição de aniversário da publicação.

Projética Revista Científica de Design I Universidade Estadual de Londrina I V.2 I N.1 I Junho 2011 


\section{Considerações finais}

Por meio deste artigo se pôde compreender a interdisciplinaridade que ocorre entre o Design e a Comunicação através de uma revisão bibliográfica de autores como Rafael Cardoso, Ivani Fazenda, Vilém Flusser, entre outros. Abordou-se a individualidade e da profundidade de significados de ambas e como apesar disso, elas podem se utilizar de fatores uma da outra para desenvolver projetos.

Demonstrou-se mediante aos elementos de análise, das duas áreas do conhecimento, como a interação entre elas pode proporcionar um produto final mais conciso e completo. As afirmações anteriores foram ilustradas através das capas da revista "CLAUDIA", onde nota-se a relação produtiva dos elementos do Design e da Comunicação - como o slogan, a tipografia, a fotografia, as cores, a logo e a diagramação - na disposição do layout da capa e todos estes fatores ao serem desenvolvidos juntos e com o mesmo propósito proporcionam ao trabalho maior valor, precisão e complexidade.

\section{Referências}

CARDOSO, Rafael. Uma introdução a história do design. Rio de Janeiro: Edgard Blucher, 2004.

CARLOS, Jairo Gonçalves. Interdisciplinaridade no ensino médio: desafios e potencialidade: interdisciplinaridade: o que é isso? 2009. Disponível em: <http://vsites.unb.br/ppgec/ dissertacoes/proposicoes/proposicao_jairocarlos.pdf>. Acesso em: 23 mar. 2011.

FAZENDA, Ivani C. Arantes. Interdisciplinaridade: história, teoria e pesquisa. Campinas: Papirus, 2003.

FLUSSER, Vilém. O mundo codificado: por uma filosofia de design e da comunicação. São Paulo: Cosac Naify, 2007.

MARTIM, Leandro de Jesus. Interdisciplinaridade. Disponível em: <http://recantodasletras.uol. com.br/artigos/294810>. Acesso em: 6 abr. 2011.

VILLAS-BOAS, André. Identidade e cultura. Rio de Janeiro: 2AB, 2002.

. O que é [e o que nunca foi] design gráfico. Rio de Janeiro: 2AB, 2007. 